\title{
消費者による情報創造 一推論に基づく属性信念の形成一
}

\section{要約 (アブストラクト)}

消費者が日常的に接している広告や購買場面では、必ずしも自分の必要としている情報がその場に存在する わけではなく、すぐに入手できるとも限らない。しかし、そのような状況であっても、消費者は与えられた情 報のみを用いて評価や意思決定をするのではなく、推論することによって必要な情報を自ら創り出している。 消費者行動研究の領域では、他ブランド平均型推論、確率型推論、評価一致型推論、代償型推論という4つの 推論タイプの存在が明らかにされている。遂行される推論タイプが異なると導かれる結論も異なってくるため、 マーケターはそれぞれの推論がどのような要因によって生じるのか理解する必要がある。

本研究では、3つの外的要因（属性間の相関関係、市場の効率性、ブランド間知覚差異）と 2 つ内的要因 (製品カテゴリーへの馴染み、推論対象属性の重要度）に注目し、それらの要因が 4 つの推論タイプへどのよ うな影響を及ぼすのか考察している。調查を行って分析した結果、各推論タイプと5つの影響要因の関係が明 らかにされた。

\section{キーワード}

消費者行動、消費者推論、推論タイプ、属性信念

\section{1. はじめに}

消費者は与えられた情報のみを使って意思 決定するわけではない。「一を聞いて十を知 る」という言葉があるように、人間は自らの 頭の中で新たな情報を創り出すことができる。 その方法の1つに、推論というプロセスがあ る。例えば、「この自動車は保証期間が長いか ら安全性も高いだらう」といった思考は、自 らの知識や経験から得られた信念（保証期間 が長い自動車ほど安全である）に基づき、与 えられた情報（保証期間の長さ）から新たな 情報（ある自動車の安全性）を創出した例で ある。この例が示すように、たとえその製品
を初めて目にした場合やある属性に関する情 報が全くない状況であっても、消費者は当該 製品がその属性をどの程度有しているのかに ついて推論し、信念を形成することがある。

推論は消費者の情報探索コストを削減し、 意思決定プロセスに付随する労力とリスクを 軽減する役割も果たす（Ross and Creyer 1992)。また、Broniarczyk and Alba (1994)に よると、推論は製品に対する信念の源泉でも あり、消費者行動の説明や予測にとって非常 に重要な概念である。このような意識の下、 推論に関する多くの研究が蓄積されている。 それらを大別すると、特定の属性情報が入手 
不可能な場合、消費者はどのように対処する のか (Huber and McCann 1982; Lim and Kim 1992; Meyer 1981; Simmons and Lynch 1991な ど)、消費者が推論を行う際、当該ブランドに 関する情報と他ブランドに関する情報ではど ちらが大きな影響を及ぼすのか（Ford and Smith 1987; Lee and Olshavsky 1997; Moon and Tikoo 1997; Ross and Creyer 1992)、消費者推 論にはどのようなタイプがあるのか（Alba and Hutchinson 1987; Broniarczyk and Alba 1994; Chernev and Carpenter 2001; Dick et al. 1990; Simmons and Leonard 1990 など）とい う3つのテーマに分けることができる。

既存研究から、消費者推論にはさまざまな タイプがあることが明らかにされてきたが、 それらは個々の研究者の視点や関心事から断 片的に行われたものが多く、包括的な取り組 みに欠けているように思われる。具体的には、 これまでに 4 つの消費者推論タイプの存在が 指摘されているにもかかわらず、それら全て を網羅した経験的研究が行われていない。そ こで本研究では、これまでに明らかにされた 推論のタイプと影響要因についてまとめ、調 査結果から両者の関係を明確化したい。

\section{2. 消費者推論のタイプ}

まず、本研究における推論の概念規定をし ておく必要がある。消費者の推論を扱った既 存研究のほとんどが「特定の属性に関する情 報が入手不可能な場合に、利用可能な情報に 基づいてその属性水準を予測する」という状 況を想定しており、本研究もこれに従う1。一 般に、製品属性については、「タウリン $1000 \mathrm{mg}$ 配合」のような客観的特性（特性的属性とも いう）から「元気が出る」といった主観的属 性（便益的属性ともいう）、さらには「サラ リーマン」のようなシンボリック属性へと続 く階層構造が仮定されている（新倉 1999）。客
観的特性が主観的属性へと変換される過程 （知覚符号化）は、消費者推論の最も典型的な 形態の 1 つを表している。

しかし、消費者が行う推論は、客観的特性 から主観的属性を予測するパターンだけでは ない。消費者が必要としている客観的特性が 常に入手可能であるとは限らないし、たとえ それが入手可能であったとしても、いちいち 調べるのが面倒な場合もある。そのような場 合、客観的特性であっても推論対象となり得 る。清涼飲料水の「濃厚な味」というコピー から「糖分の多さ」を推論するといったよう に、主観的属性から客観的特性を予測するこ ともあるだろう。したがって、本稿では、客 観的特性と主観的属性の双方を含めた広義の 「属性」としてこの用語を使用する。

このような状況における推論を消費者推論 と呼ぶならば、既述の通り、これまでに明ら かにされた消費者推論のタイプは 4つに分類 することができる。1つ目は、「他ブランド平 均型推論 (mean inference)」である。これは 推論対象の属性について、選択集合内にある 他ブランドがもつ平均的な水準を当該ブラン ドに付与する方法である。例えば、自動車の 安全性について、ブランド $\mathrm{A}$ の情報は入手不 可能だが、ブランド B、C、Dはそれぞれ4点、 3 点、 5 点という評価を得ていることが分かっ ているとしよう。この時、ブランド $\mathrm{A}$ の安全 性はブランド $\mathrm{B} 、 \mathrm{C} 、 \mathrm{D}$ の平均值である 4 点 であろうと予測するのが他ブランド平均型推 論である。また、「どのブランドも同じ」と いった推論もこのタイプに含まれる。

2つ目は「確率型推論（probabilistic consistency inference)」であり、冒頭で示した自動 車の安全性に関する推論の例はこのタイプに 当てはまる。確率型推論とは、情報が利用可 能な属性の中から推論対象属性（安全性）と 強い相関関係にあると知覚されるもの（保証 
期間）に注目し、その関係に対する信念（保 証期間が長いほど安全性も高い）に基づいて 未知の属性水準を予測する方法である。

3つ目は「評価一致型推論（evaluative consistency inference)」であり、利用可能なあら ゆる属性情報から当該製品について総合評価 し、その評価を推論対象属性の水準とする方 法である。例えば、自動車ブランド Aの安全 性について、まず、ブランド Aに関して入手 可能な全ての属性情報 (エンジン性能、燃費、 内装など）を用いて総合評価を導出する。そ の結果、ブランド Aが総合的にみて中レベル の自動車であると判断されたならば、ブラン ドAの安全性も中レベルだろうと予測するの が評価一致型推論である。

4 つ目は、「代償型推論 (compensatory inference)」である。これは、「同一価格（帯） の製品であれば、提供される総合的なべネ フィットも同一である」という前提の下、総 合評価が同一水準になるよう推論対象属性の 水準を予測する方法である。例えば、ブラン ド Aとブランド B という自動車の価格は同一 だが、燃費とエンジン性能という点でブラン ドAはブランドBよりも優れていたとする。ブ

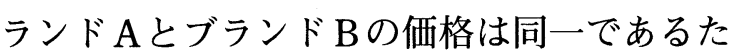
め総合的なべネフィットが同一レベルにある と考えるならば、燃費とエンジン性能以外の 属性においてブランド B はブランド Aよりも 優れていなければならない。このような観点 から、安全性ではブランド Aがブランド Bよ りも劣っていると予測するのが代償型推論で ある。

したがって、代償型推論と評価一致型推論 では反対の結論が導かれることになるわけだ が、Chernev and Carpenter（2001）によると、 両者を分ける要因は「市場の効率性（market efficiency)」にあるという。市場の効率性と は、観測される総合的なべネフィットと価格
の比例関係性を表す。つまり、効率性の高い 市場において、他の条件が一定であれば、あ る属性の水準が 1 単位増加することはその分 の価格上昇を意味し（Rosen 1974）、同一価格 の製品であれば総合的にみて等しい価值が提 供される（Lichtenstein and Burton 1989; Rao and Monroe 1988）。そのような市場は情報探 索コストが低く、ベネフィットが明瞭であり、 ベネフィット評価が容易であるという特徴を 有しているため、消費者にとって「効率性が 高い」市場であるということができる (Chernev and Carpenter 2001)。

\section{3. 推論タイプと影響要因の関係}

\section{1 外的要因}

推論タイプの比較を行ったBroniarczyk and Alba（1994）と Dick et al.（1990）の実験では いずれも確率型推論の遂行が最も多く見られ、 次いで評価一致型推論が多く、他ブランド平 均型推論を行う被験者の割合は最も少なかっ た。こうした違いに影響を及ぼす外的要因は、 市場の効率性だけではない。

Chernev and Carpenter（2001）は属性間の 相関関係が強い場合、確率型推論を行う消費 者の割合が最も高く、属性間の相関関係が弱 い場合、市場の効率性が低ければ評価一致型 推論、効率性が高ければ代償型推論を遂行す る割合が高くなることを明らかにした。Moon and Tikoo（1997）は属性間の相関関係が存在 する場合は確率型推論が行われやすく、他ブ ランド平均型推論は属性間の相関関係もブラ ンド間知覚差異もない場合に多く遂行される とした。

「属性間の相関関係」とは、情報が入手可能 な属性の中で推論対象属性と相関関係にある ような属性の有無、およびその強さを表す。 すなわち、「安全性」に対する「保証期間」や 「虫菌予防」に対する「キシリトール配合」の 
ように、未知の属性水準を端的に表す属性情 報が利用可能かどうかである。属性間の相関 関係は、個別の 2 属性間に関するものである という点で、総合的なべネフィットを問題と する市場の効率性とは異なる。このように、2 つの事象や概念間の関係あるいはその結びつ きの程度に関して形成される消費者の信念は 共変信念 (covariation belief) と呼ばれ (Bettman et al. 1986; 新倉 1996,1999)、推論 ルールを創出する役割を果たすといわれる (Pechmann and Ratneshwar 1992; 新倉 1997)。

また、「ブランド間知覚差異」とは、推論対 象の属性に関して知覚される選択集合の異質 性（ばらつき）のことである。ブランド間知 覚差異も、1つの属性を対象としている点で 市場の効率性とは異なる。以上のような既存 研究の成果をまとめると、図1のようなフ ローチャートを作成することができる。

図1から、外的要因の中で最も大きな影響 力をもつのは属性間の相関関係であり、これ に該当する属性が存在する場合、他の要因に 関わらず確率型推論の割合が増えることが分 かる。その結果、他の推論タイプの割合は必 然的に減少すると考えられる。ゆえに、次の ような仮説が導出される。
$\mathrm{H} 1 \mathrm{a}$ 属性間の相関関係が強いほど、確率型推 論を遂行する消費者の割合が大きくなる

$\mathrm{H} 1 \mathrm{~b}$ 属性間の相関関係が強いほど、代償型推 論を遂行する消費者の割合が小さくなる

H1c 属性間の相関関係が強いほど、評価一致 型推論を遂行する消費者の割合が小さく なる

H1d 属性間の相関関係が強いほど、他ブラン ド平均型推論を遂行する消費者の割合が 小さくなる

確率型推論の遂行は属性間の相関関係に よってのみ規定されるため、市場の効率性と ブランド間知覚差異の影響は受けない。代償 型推論は属性間の相関関係が弱く、市場の効 率性が高い場合に増える。一方、評価一致型 推論と他ブランド平均型推論は市場の効率性 が低い場合に遂行されやすくなる。ゆえに、 市場の効率性について次のような仮説が導出 される。

H2a 市場の効率性が高いほど、代償型推論を 遂行する消費者の割合が大きくなる

$\mathrm{H} 2 \mathrm{~b}$ 市場の効率性が高いほど、評価一致型推 論を遂行する消費者の割合が小さくなる H2c 市場の効率性が高いほど、他ブランド平 均型推論を遂行する消費者の割合が小さ くなる

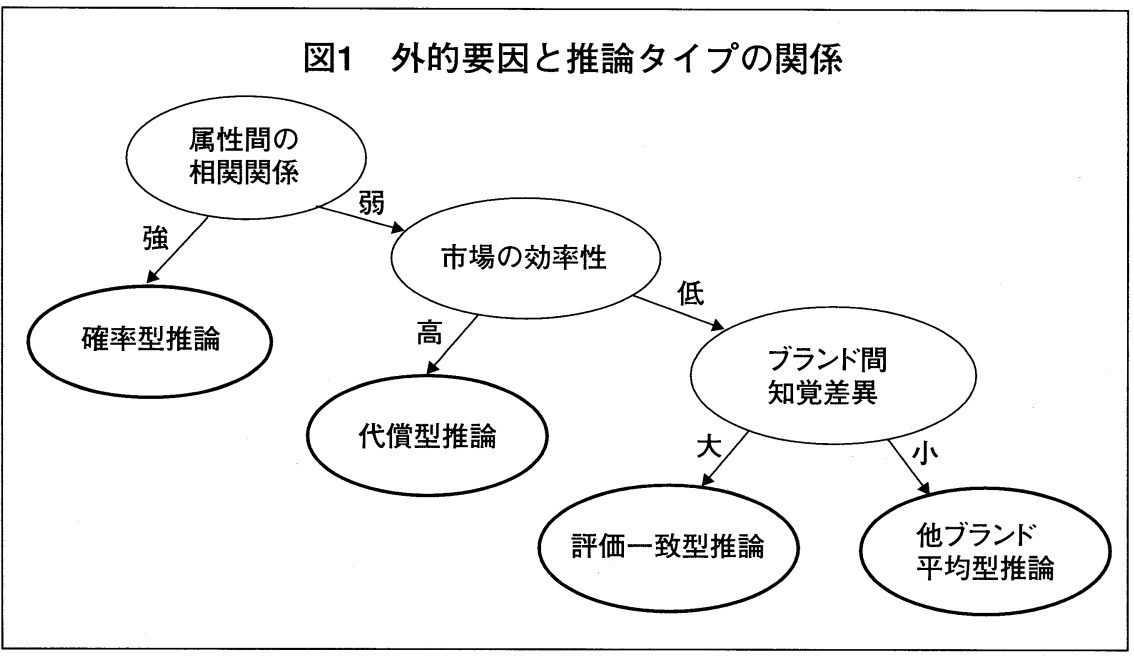

代償型推論は属性間の相 関関係が弱く、市場の効率 性が高い場合に増えるため、 ブランド間知覚差異の影響 を受けない。評価一致型推 論は（属性間の相関関係が 弱く、市場の効率性が低く） ブランド間知覚差異が大き い時、他ブランド平均型推 
論は（属性間の相関関係が弱く、市場の効率 性が低く）ブランド間知覚差異が小さい時に 遂行されやすくなる。ゆえに、ブランド間知 覚差異について次のような仮説が導出される。

H3a ブランド間知覚差異が大きいほど、評価 一致型推論を遂行する消費者の割合が大 きくなる

$\mathrm{H} 3 \mathrm{~b}$ ブランド間知覚差異が大きいほど、他ブ ランド平均型推論を遂行する消費者の割 合が小さくなる

\section{2 内的要因}

どの推論タイプが遂行されるかは、消費者 の内的要因によっても影響を受ける。既存研 究は製品カテゴリーへの馴染み（製品知識、 使用経験）が推論に影響を及ぼすことを示し ているが (Alba and Hutchinson 1987; Chernev and Carpenter 2001; Lee and Olshavsky 1997; Meyer 1981 など)、経験的テストに基づく妥 当性の検証は行われていない。

中西（1984）は「一般に、当該商品を含む 商品分野の全体について経験を蓄積するにし たがい、知覚符号化はある主観的属性とその 判断資料となる客観的特性との単純な対応と して簡略化される」ようになり、「消費者は客 観的（物理的）特性の中からいくつか特性 のみに注目し、その他の特徵は無視するよう になる」と述べている2。知覚符号化は推論 (と りわけ確率型推論）と非常に近い概念である ため、この主張は本稿の議論にも適用可能で ある。つまり、製品カテゴリーへの馴染みが 深くなる（経験を蓄積する）ほど、消費者は 良き判断材料となる属性間の相関関係に注目 することが可能となり、確率型推論を行いや すくなると考えられる。

また、Chernev and Carpenter (2001) は、代 償型推論を行うためには当該市場に関する詳
細な知識が必要であるとし、製品カテゴリー への馴染みが深いほど代償型推論が遂行され やすくなると述べている。さらに、Lee and Olshavsky（1997）は、多くの事例を基に平均 值を算出する他ブランド平均型推論の遂行に もハイレベルな製品知識や豊富な使用経験が 必要であると主張した。

しかし、「どれも同じ」という方法で遂行さ れる場合は、たとえ製品知識の乏しい消費者 (novice) であっても他ブランド平均型推論は 容易に実行できる。したがって、本研究では、 他ブランド平均型推論は製品カテゴリーへの 馴染みによる影響を受けないと考える。同様 に、評価一致型推論も利用可能な属性情報に 基づく評価を推論対象の属性に当てはめれば よいので、製品カテゴリーへの馴染みに関係 なく遂行可能である。ゆえに、この要因は評 価一致型推論へ影響を及ぼさないと予想され る。以上の議論から、次のような仮説が導出 される。

H4a 製品カテゴリーへの馴染みが深いほど、 確率型推論を遂行する消費者の割合が大 きくなる

$\mathrm{H} 4 \mathrm{~b}$ 製品カテゴリーへの馴染みが深いほど、 代償型推論を遂行する消費者の割合が大 きくなる

最後に、属性の重要度も推論タイプの違い に影響を及ぼすと思われる。ここで、属性の 重要度とは消費者が推論対象属性をどの程度 重要視しているかということである。推論対 象属性が重要である場合、消費者はより直接 的な方法で当該属性について判断しようとす るだろう。したがって、未知の属性水準を端 的に示すことのできる情報、すなわち当該属 性と相関関係にある属性を積極的に活用しよ うとすることが予想される。ゆえに、次のよ 
うな仮説が導出される（表 1 には、本研究の 仮説がまとめられている)。

H5 推論対象属性の重要度が高いほど、確率 型推論を遂行する消費者の割合が大きく なる

\begin{tabular}{|c|c|c|c|c|c|}
\hline \multirow[b]{4}{*}{ 推論タイプ } & \multicolumn{5}{|c|}{ 表1 推論タイプと影響要因の関係 } \\
\hline & \multicolumn{5}{|c|}{ 影響要因 } \\
\hline & \multicolumn{3}{|c|}{ 外的要因 } & \multicolumn{2}{|c|}{ 内的要因 } \\
\hline & $\begin{array}{l}\text { 属性間の } \\
\text { 相関関係 }\end{array}$ & $\begin{array}{l}\text { 市場の } \\
\text { 効率性 }\end{array}$ & $\begin{array}{l}\text { ブランド間 } \\
\text { 知覚差異 }\end{array}$ & $\begin{array}{l}\text { 製品カテゴリー } \\
\text { ヘの馿染み }\end{array}$ & $\begin{array}{l}\text { 属性の } \\
\text { 重要度 }\end{array}$ \\
\hline 確率型 & $+\left(\mathrm{H}_{1 \mathrm{a}}\right)$ & & & $+\left(\mathrm{H}_{4 a}\right)$ & $+\left(\mathrm{H}_{5}\right)$ \\
\hline 代償型 & $-\left(H_{1 b}\right)$ & $+\left(\mathrm{H}_{2 \mathrm{a}}\right)$ & & $+\left(\mathrm{H}_{4 \mathrm{~b}}\right)$ & \\
\hline 評価一致型 & $-\left(H_{1 c}\right)$ & $-\left(\mathrm{H}_{2 b}\right)$ & $+\left(\mathrm{H}_{3 a}\right)$ & & \\
\hline 他ブランド平均型 & $-\left(H_{1 d}\right)$ & $-\left(H_{2 c}\right)$ & $-\left(\mathrm{H}_{3 \mathrm{~b}}\right)$ & & \\
\hline
\end{tabular}

した (市場の効率性の測定)。測定尺度は 5 ポ イントの間隔尺度（1：そう思わない〜 5：そ う思う）である。

調査の結果、7つの製品カテゴリーの中で は「ミネラルウォーター」の平均值 (3.52) が 最も高く、「ワイン」の平均值 (1.90) が最も 低かった $(\mathrm{p}<0.01)^{3}$ 。よって、市 場の効率性が高い製品カテゴ リーをミネラルウォーターとし、 市場の効率性が低い製品カテゴ リーをワインとした。

\section{4. 調查}

本調査の目的は、3つの外的要因 (属性間の 相関関係、市場の効率性、ブランド間知覚差

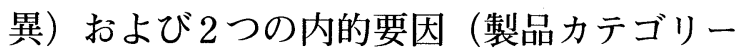
への馴染み、属性の重要度）と各推論タイプ の関係を明らかにすることである。そこで、 （1）相関関係が強い属性と弱い属性、（2）市 場の効率性が高い製品カテゴリーと低い製品 カテゴリー、（3）ブランド間知覚差異が大き い属性と小さい属性を抽出するための事前調 査を実施し、その後本調査を行った。

\section{1 事前調査 1}

調査に使用する製品カテゴリーを選定する ため、早稲田大学大学院商学研究科に在籍す る大学院生 21 名を対象に事前調查を実施し た。ここでは7つの製品カテゴリー（ノート パソコン、プリンター、デジタルカメラ、ワ イン、ミネラルウォーター、インターネット・ サービス・プロバイダー、スポーツジム)を 対象に「価格が同一であれば、どのメーカー やブランドの製品を購入しても、総合的な品 質はほとんど同じだと思うか」という質問を

\section{2 事前調査 2}

次に、事前調查1の結果から選択された $2 つ$ の製品カテゴリーの中で、相関関係が強い属 性と弱い属性、およびブランド間知覚差異が 大きい属性と小さい属性を抽出する必要があ る。そこで、事前調查 1 の実施から一週間後、 同一の回答者を対象に 2 回目の事前調査を実 施した（n=21）。

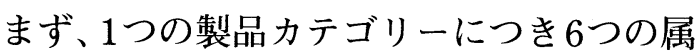
性を示し、各属性について「メーカーやブラ ンドによって差があると思うか」という質問 をした (ブランド間知覚差異の測定) 4 。次に、 全ての属性の組み合わせについて、両者の間 に「関係があると思うか」という質問をした (属性間の相関関係の測定)。測定尺度にはい ずれも 5 ポイントの間隔尺度（1：そう思わな い〜5：そう思う）を用いた。

その結果、ミネラルウォーターのブランド 間知覚差異では「ミネラル含有量」が最も大 きく「(製品の) 安全性」が最も小さかった (平 均值はそれぞれ 4.33、3.29、t=3.86、 $\mathrm{p}<0.01$ )。 一方、ワインのブランド間知覚差異では「味 の深み」が最も大きく「健康効果」が最も小 
さかった（同じく4.10、3.38、 $\mathrm{t}=3.63 、 \mathrm{p}<0.01 ） 。$ そこで、ミネラルウォーターの「ミネラル含 有量」およびワインの「味の深み」をブラン ド間知覚差異が大きい属性とし、ミネラル ウォーターの「安全性」とワインの「健康効 果」をブランド間知覚差異が小さい属性とし た。これらは、本調査において推論対象（欠 測情報）となる属性である。

ここで、選ばれた推論対象属性と他の属性 との相関関係に着目し、相関関係に差がある （1つだけ他よりも相関の高い属性、すなわち 注目すべき属性が含まれている）グループと 相関関係に差がないグループに分けようと試 みた。多重比較 (Dunnettの検定) を行って検 討した結果、提示される属性数は 3 つに絞ら れた 5 。表 2 には、推論対象属性と提示される 属性の相関関係が示されている。

\section{3 本調査}

本調査は 2004 年 5 月 14 日、早稲田大学商学 部に在籍する20歳以上の学生306名 (男性 198 名、女性 108 名）を対象に実施した。ここで は、回答者を 2 (属性間の相関関係: 強/弱) $\times 2$ (市場の効率性 : 高／低） $\times 2$ (ブランド 間知覚差異：大／小）の 8 群へランダムに振 り分け、群ごとに条件の異なる1つの推論課

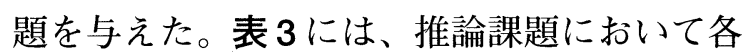
群に提示される属性と推論対象属性が示され ている。

推論課題では、冒頭に『3つの製品の価格 は同一ですが、それぞれの製品に対し、「属性 $\mathrm{A} 」\lceil$ 属性 B」「属性 C」について 5 点満点で専 門家（店舗やメーカーとは無関係の人物）が 評価しています。という文章を提示した。そ の後に専門家の評価を表示し、それを参考に 推論対象属性の水準が最も高いと思うブラン ドについて「ブランドA、B、C、どれも同じ」の

表2 属性間の相関関係

1. ミネラルウォーター（市場の効率性：高)

\begin{tabular}{|c|c|c|c|c|c|c|}
\hline 群 & 属性 & $\begin{array}{c}\text { ミネラル含有量 } \\
\text { との相関 }\end{array}$ & 多重比較 & 属性 & $\begin{array}{l}\text { 安全性 } \\
\text { との相関 }\end{array}$ & 多重比較 \\
\hline $\begin{array}{l}\text { 強 } \\
\text { 相 } \\
\text { 関 }\end{array}$ & $\begin{array}{l}\mathrm{A}: \text { 原産地の自然環境 } \\
\mathrm{B}: \text { ダイエット効果 } \\
\mathrm{C}: \text { 安全性 }\end{array}$ & $\begin{array}{l}4.62 \\
3.29 \\
3.29\end{array}$ & $\begin{array}{l}\text { A-B間、A-C間に有 } \\
\text { 意差あり（いずれも } \\
p<0.01 ）\end{array}$ & $\begin{array}{l}\mathrm{A}: \text { 原産地の自然環境 } \\
\mathrm{B}: \text { ダイエット効果 } \\
\mathrm{C}: \text { 飲みやすさ }\end{array}$ & $\begin{array}{l}3.76 \\
2.62 \\
2.86\end{array}$ & $\begin{array}{l}A-B \text { 間、A-C間に有 } \\
\text { 意差あり（いずれも } \\
p<0.01 ）\end{array}$ \\
\hline $\begin{array}{l}\text { 弱 } \\
\text { 相 } \\
\text { 関 }\end{array}$ & $\begin{array}{l}\mathrm{A}: \text { 飲みやすさ } \\
\mathrm{B}: \text { ダイエット効果 } \\
\mathrm{C}: \text { : 安全性 }\end{array}$ & $\begin{array}{l}3.57 \\
3.29 \\
3.29\end{array}$ & 有意差なし & $\begin{array}{l}\text { A：健康効果 } \\
\mathrm{B}: \text { ダイエット効果 } \\
\mathrm{C}: \text { 飲みやすさ }\end{array}$ & $\begin{array}{l}3.05 \\
2.62 \\
2.86 \\
\end{array}$ & 有意差なし \\
\hline
\end{tabular}

2. ワイン（市場の効率性：低）

\begin{tabular}{|c|c|c|c|c|c|c|}
\hline 群 & 属性 & $\begin{array}{l}\text { 味の深み } \\
\text { との相関 }\end{array}$ & 多重比較 & 属性 & $\begin{array}{l}\text { 健康効果 } \\
\text { との相関 } \\
\end{array}$ & 多重比較 \\
\hline $\begin{array}{l}\text { 強 } \\
\text { 相 } \\
\text { 関 }\end{array}$ & $\begin{array}{l}\mathrm{A}: \text { : 生産地の気候条件 } \\
\mathrm{B}: \text { 生産者のレベル } \\
\mathrm{C}: \text { 健康効果 }\end{array}$ & $\begin{array}{l}4.33 \\
3.48 \\
3.10 \\
\end{array}$ & $\begin{array}{l}\text { A-B間、A-C間に有 } \\
\text { 意差あり（いずれも } \\
\text { p<0.01） }\end{array}$ & $\begin{array}{l}\mathrm{A}: \text { :゚リフェノール含有量 } \\
\mathrm{B}: \text { 生産地の土堙条件 } \\
\mathrm{C}: \text { 味の深み }\end{array}$ & $\begin{array}{l}4.14 \\
3.14 \\
3.10 \\
\end{array}$ & $\begin{array}{l}A-B \text { 間、A-C間に有 } \\
\text { 意差あり（いずれも } \\
\text { p<0.01） }\end{array}$ \\
\hline $\begin{array}{l}\text { 弱 } \\
\text { 相 } \\
\text { 関 }\end{array}$ & $\begin{array}{l}\text { A : ポリフェノール含有量 } \\
\text { B : 生産者のレベル } \\
\mathrm{C}: \text { 健康効果 }\end{array}$ & $\begin{array}{l}3.71 \\
3.48 \\
3.10 \\
\end{array}$ & 有意差なし & $\begin{array}{l}\mathrm{A}: \text { : 生産地の気候条件 } \\
\mathrm{B}: \text { 生産地の土䁃条件 } \\
\mathrm{C}: \text { 味の深み }\end{array}$ & $\begin{array}{l}3.48 \\
3.14 \\
3.10 \\
\end{array}$ & 有意差なし \\
\hline
\end{tabular}

注）表中の数值は「属性間の相関関倸」の測定スコア (平均值) である。

表3 推論課題で提示される属性と推論対象属性

\begin{tabular}{|c|c|c|c|c|c|}
\hline \multirow{2}{*}{\multicolumn{2}{|c|}{$\begin{array}{c}\text { 市場の効率性 } \\
\text { ブランド間知覚差異 }\end{array}$}} & \multicolumn{2}{|c|}{ 高：ミネラルウォーター } & \multicolumn{2}{|c|}{ 低：ワイン } \\
\hline & & 大 & 小 & 大 & 小 \\
\hline & 対象属性 & ミネラル含有量 & 安全性 & 味の深み & 健康効果 \\
\hline 提 & 強相関 & $\begin{array}{l}\text { - 原産地の自然環境 } \\
\text { ・ ダイエット効果 } \\
\text { ・安全性 }\end{array}$ & $\begin{array}{l}\text { ·原産地の自然環境 } \\
\text { •ダイエット効果 } \\
\text { • 飲みやすさ }\end{array}$ & $\begin{array}{l}\text { ·生産地の気候条件 } \\
\text { - 生産者のレベル } \\
\text { - 健康効果 }\end{array}$ & $\begin{array}{l}\cdot \text { ・゚リフェノール含有量 } \\
\text { ・生産地の土䁃条件 } \\
\text { ・味の深み }\end{array}$ \\
\hline $\begin{array}{l}\text { 势 } \\
\text { 属 } \\
\text { 性 }\end{array}$ & 弱相関 & $\begin{array}{l}\text { ・飲みやすさ } \\
\text { ・ダイエット効果 } \\
\text { ・安全性 }\end{array}$ & $\begin{array}{l}\text { - 健康効果 } \\
\text { ・ダイエット効果 } \\
\text { ・ 飲みやすさ }\end{array}$ & $\begin{array}{l}\text { - ポリフェノール含有量 } \\
\text { • 生産者のレベル } \\
\text { - 健康効果 }\end{array}$ & $\begin{array}{l}\text { ·生産值の気候条件 } \\
\text { • 生産地の土壤条件 } \\
\text { - 味の深み }\end{array}$ \\
\hline
\end{tabular}


中から1つ選択させた(詳しくはくAppendix〉 を参照されたい)。

ここで、いずれの群においても、属性 A は 推論対象属性との相関関係が（提示される属 性の中で）最も高いものにした（属性 A は、 表 2 にある属性闌の A に等しい)。その上で、 ブランド A は属性 Aの評価が最高となるよう にし、ブランド B は合計点が最低、ブランド C は合計点が最高となるように点数を配分し た。こうすることによって、ブランド A、B、 Cを選択した回答者がそれぞれ確率型、代償 型、評価一致型の推論を遂行したものとして 処理できると考えた。また、「どれも同じ」は 他ブランド平均型推論の遂行として処理し た6。

推論課題に続き、回答を訂正しないよう注 意した上で、操作チェック用の（外的要因に 関する) 質問を設けた7。さらに、内的要因 (製 品カテゴリーへの馴染み、属性の重要度）に 関する質問も行った。製品カテゴリーへの馴 染みは「購入頻度」「使用頻度」「知識」とい う 3 項目で測定し、属性の重要度は提示され た属性と推論対象属性の計 4 属性を対象に、 「購入する際に重要だと思う順」に番号をつけ
てもらうという方法で測定した。

\section{5. 結果と分析}

\section{1 操作チェック}

属性間の相関関係、市場の効率性、ブラン ド間知覚差異の操作が成功しているかチェッ クするため、それぞれの平均值を群別に比較 した。その結果、強相関群と弱相関群 (3.86、 2.79、 $\mathrm{t}=7.11 、 \mathrm{p}<0.01)$ 、高効率性群と低効率性 群 $(2.38 、 2.02 、 \mathrm{t}=2.44 、 \mathrm{p}<0.05)$ 、および大知 覚差異群と小知覚差異群 $(4.13 、 3.77 、 \mathrm{t}=2.47$ 、 $\mathrm{p}<0.05 ）$ の間にはいずれも有意差が確認され た。

\section{2 分析 1}

表 4 には、遂行された推論タイプの割合が 群別に示されている。比率の差の検定を行っ た結果、群による有意差が確認された（ $\chi^{2}$ $(21)=101.718 、 \mathrm{p}<0.01)$ 。よって、8つの群 間で推論タイプの遂行割合に違いがあること が明らかになった。

残差分析 (Haberman法) の結果、強相関／ 高効率性 /大知覚差異群、強相関 /高効率性 ／小知覚差異群および強相関／低効率性／小

表4 群別の遂行割合

\begin{tabular}{|c|c|c|c|c|}
\hline \multirow{2}{*}{$\begin{array}{c}\text { 群 } \\
\text { (相関 /効率性 /知覚差異) }\end{array}$} & \multicolumn{4}{|c|}{ 推論結果 (\%) } \\
\hline & 確率型 & 代償型 & 評価一致型 & 他ブランド平均型 \\
\hline 強／高／大 $(n=39)$ & $\begin{array}{l}69.2^{\star \star \star} \\
(3.33) \\
\end{array}$ & $\begin{array}{c}0.0 \\
(-1.30) \\
\end{array}$ & $\begin{array}{l}23.1^{\star \star \star} \\
(-2.93) \\
\end{array}$ & $\begin{array}{c}7.7 \\
(0.19) \\
\end{array}$ \\
\hline 強／高／小 (n=38) & $\begin{array}{c}78.9^{\star \star \star} \\
(4.57) \\
\end{array}$ & $\begin{array}{c}0.0 \\
(-1.28) \\
\end{array}$ & $\begin{array}{l}13.2^{\star \star \star} \\
(-4.20) \\
\end{array}$ & $\begin{array}{c}7.9 \\
(0.24) \\
\end{array}$ \\
\hline 強／低／大 $(n=38)$ & $\begin{array}{c}42.1 \\
(-0.32) \\
\end{array}$ & $\begin{array}{c}0.0 \\
(-1.28) \\
\end{array}$ & $\begin{array}{c}55.3 \\
(1.38) \\
\end{array}$ & $\begin{array}{c}2.6 \\
(-1.12)\end{array}$ \\
\hline 強／低／小 (n=36) & $\begin{array}{r}58.3^{*} \\
(1.78) \\
\end{array}$ & $\begin{array}{c}0.0 \\
(-1.25) \\
\end{array}$ & $\begin{array}{c}41.7 \\
(-0.41)\end{array}$ & $\begin{array}{c}0.0^{\star} \\
(-1.75) \\
\end{array}$ \\
\hline 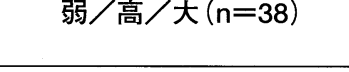 & $\begin{array}{l}23.7^{\star \star *} \\
(-2.76)\end{array}$ & $\begin{array}{c}13.2^{\star \star \star} \\
(3.34)\end{array}$ & $\begin{array}{c}47.4 \\
(0.33) \\
\end{array}$ & $\begin{array}{l}15.8^{\star \star} \\
(2.28)\end{array}$ \\
\hline 弱／高／小 (n=39) & $\begin{array}{c}56.4 \\
(1.60) \\
\end{array}$ & $\begin{array}{l}10.3^{\star \star} \\
(2.36)\end{array}$ & $\begin{array}{l}25.6^{\star \star \star} \\
(-2.59)\end{array}$ & $\begin{array}{c}7.7 \\
(0.19) \\
\end{array}$ \\
\hline 弱／低／大 (n=37) & $\begin{array}{l}13.5^{\star \star \star} \\
(-4.05) \\
\end{array}$ & $\begin{array}{c}2.7 \\
(-0.33) \\
\end{array}$ & $\begin{array}{c}78.4^{\star \star \star} \\
(4.38)\end{array}$ & $\begin{array}{c}5.4 \\
(-0.40) \\
\end{array}$ \\
\hline 弱／低／小 $(n=36)$ & $\begin{array}{l}11.1^{\star \star \star} \\
(-4.30) \\
\end{array}$ & $\begin{array}{c}2.8 \\
(-0.30) \\
\end{array}$ & $\begin{array}{l}77.8^{\star \star \star} \\
(4.23) \\
\end{array}$ & $\begin{array}{c}8.3 \\
(0.34) \\
\end{array}$ \\
\hline 合計 $(n=301)$ & 44.5 & 3.7 & 44.9 & 7.0 \\
\hline$\chi^{2}(21)=101.718$ & ※ & み残差 & ***1\%水準 & *10\%水準 \\
\hline
\end{tabular}


知覚差異群において確率型推論の遂行割合が 期待值よりも有意に大きく（それぞれ 69.2\%、 $\mathrm{p}<0.01 、 78.9 \% 、 \mathrm{p}<0.01 、 58.3 \% 、 \mathrm{p}<0.10) 、$ 弱 相関／高効率性／大知覚差異群、弱相関／低 効率性／大知覚差異群、および弱相関／低効 率性／小知覚差異群ではその割合が期待値よ りも有意に小さいことが明らかになった（そ れぞれ 23.7\%、13.5\%、11.1\%、全て $\mathrm{p}<0.01$ 、 表 4 を参照)。ここから、確率型推論には市場 の効率性やブランド間知覚差異よりも属性間 の相関関係が大きな影響を及ぼし、相関関係 が強い場合に当該推論を遂行する割合が大き くなるという傾向が見て取れる。

代償型推論について見ると、弱相関／高効 率性 /大知覚差異群と弱相関 /高効率性 /小 知覚差異群の遂行割合が期待值よりも有意に 大きくなっている（それぞれ $13.2 \% 、 \mathrm{p}<0.01$ 、 $10.3 \% 、 \mathrm{p}<0.05)$ 。この結果は、属性間の相関 関係が弱く、市場の効率性が高いと代償型推 論の割合が大きくなるという予想と一致した 傾向を示している。また、属性間の相関関係 が弱く市場の効率性が低い場合は、ブランド 間知覚差異が大きければ評価一致型推論の割 合が大きくなり、ブランド間知覚差異が小さ ければ他ブランド平均型推論の割合が大きく なると予想した。分析の結果、弱相関／低効 率性／大知覚差異群では評価一致型推論の割 合が大きかったが $(78.4 \% 、 \mathrm{p}<0.01)$ 、弱相関 ／低効率性／小知覚差異群における他ブラン ド平均型推論の割合（8.3\%、p $>0.10 ）$ は大き くなかった。

ところで、本節で行った分析は内的要因の 影響を考慮していない。また、外的要因につ いても、比率の差の検定や残差分析では各要 因がもつ影響力の大きさを詳しく捉えること ができない8。そこで次節では、内的要因に関 する質問への回答も利用し、ロジスティック 回帰分析を行って 5 つの影響要因と推論タイ
プの関係についてより詳細に検討したい。

\section{3 分析 2}

本節では、推論結果を推論タイプごとに二 值変数へ変換し（遂行: $\mathrm{Y}=1$ 、非遂行: $\mathrm{Y}=0$ ）、 これを目的変数とするロジスティック回帰分 析を行う。説明変数は 5 つの影響要因であり、 各要因に関する質問への回答を利用した。た だし、製品カテゴリーへの馴染みは 3 項目で 測定したので、それらの平均值を使用してい る(Cronbach's $\alpha=0.80)$ 。また、属性重要度 では、推論対象属性に対して付与された順位 を量的に扱った 9 。なお、変数選択にはステッ プワイズ法（変数減少法）を用い、モデルの 採択は適合度の高さと組み込まれた説明変数 の多さを基準にした ${ }^{10}$ 。

\section{- 確率型推論}

表 5-1 には、確率型推論の遂行／非遂行を 目的变数とするロジスティック回帰分析の結 果が示されている。確率型推論では、属性間 の相関関係におけるオッズ比が 1 よりも大き くなっている $(\operatorname{Exp}(\mathrm{B})=1.807 、 \mathrm{p}<0.01)$ 。これ は、属性間の相関関係が 1 単位増加すると、 確率型推論遂行のオッズ（当該推論が遂行さ れる確率を $\pi$ とした時の $\pi /(1-\pi)$ で表され る）が高まる（80.7\%増になる）ことを意味す る。つまり、属性間の相関関係が強くなると 確率型推論が遂行されやすくなるといえるの で、H1aは支持された。

内的要因についてみてみると、製品カテゴ リーへの馴染みもオッズ比が 1 より大きく なっている $(\operatorname{Exp}(\mathrm{B})=1.283 、 \mathrm{p}<0.05)$ 。っ て、製品カテゴリーへの馴染みが深まると確 率型推論が遂行されやすくなるといえるので、 H4a は支持された。属性重要度ではオッズ比 が1より小さくなっているが $(\operatorname{Exp}(\mathrm{B})=0.818$ 、 $\mathrm{p}<0.10)$ 、前述したように当該变数は順位とし 
ての数值を量的に扱ったものなので、この值 が増加することは重要度が低くなることを意 味する。したがって、符号の意味を他の説明 変数とは逆に解釈しなければならない。つま り、属性重要度のオッズ比が 1 より小さいと いうことは、重要度が高まるにつれて確率型 推論が遂行されやすくなることを表す。ゆえ に、 $\mathrm{H} 5$ は支持された。

なお、確率型推論のロジスティック回帰モ デル（表5-1）には市場の効率性が含まれてい ないが、これは当該説明変数のパラメータ推
定值が有意になることはなく、なおかつこれ を含めた場合にモデルの適合度が低かったこ とによる。したがって、市場の効率性は確率 型推論の遂行へ影響を及ぼさないと考えるの が妥当だろう。

\section{・代償型推論}

表 5-2 には、代償型推論の遂行／非遂行を 目的変数とするロジスティック回帰分析の結 果が示されている。代償型推論では、属性間 の相関関係におけるオッズ比が 1 よりも小さ

表5 ロジスティック回帰分析の結果

1. 確率型推論

\begin{tabular}{|c|c|c|c|c|c|c|}
\hline & \multirow{2}{*}{ B } & \multirow{2}{*}{ Wald } & \multirow{2}{*}{ 有意確率 } & \multirow{2}{*}{$\begin{array}{l}\text { オッズ比 } \\
(\operatorname{Exp}(B))\end{array}$} & \multicolumn{2}{|c|}{ Exp (B) の95.0\%信頼区間 } \\
\hline & & & & & 下限 & 上限 \\
\hline 相関関係 & 0.592 & 36.193 & 0.000 & $1.807^{\star \star \star}$ & 1.490 & 2.192 \\
\hline 知覚差異 & -0.104 & 1.084 & 0.298 & 0.901 & 0.741 & 1.096 \\
\hline 馴染み & 0.249 & 4.909 & 0.027 & $1.283^{\star \star}$ & 1.029 & 1.600 \\
\hline 属性重要度 & -0.201 & 2.968 & 0.085 & $0.818^{\star}$ & 0.650 & 1.028 \\
\hline 定数 & -2.008 & 10.288 & 0.001 & $0.134^{\star \star \star}$ & & \\
\hline \multirow{2}{*}{\multicolumn{2}{|c|}{$\chi^{2}(8)=14.648 p=0.066$}} & \multicolumn{3}{|c|}{ 予測値の正分類:72.8\% } & \multicolumn{2}{|c|}{ 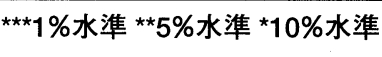 } \\
\hline & & \multicolumn{3}{|c|}{ 2. 代償型推論 } & & \\
\hline & \multirow{2}{*}{ B } & \multirow{2}{*}{ Wald } & \multirow{2}{*}{ 有意確率 } & \multirow{2}{*}{$\begin{array}{l}\text { オッズ比 } \\
(\operatorname{Exp}(B))\end{array}$} & \multicolumn{2}{|c|}{ Exp (B) の95.0\%信頼区間 } \\
\hline & & & & & 下限 & 上限 \\
\hline 相関関係 & -0.603 & 5.957 & 0.015 & $0.547^{\star \star}$ & 0.337 & 0.888 \\
\hline 効率性 & 0.501 & 4.580 & 0.032 & $1.651^{\star \star}$ & 1.043 & 2.612 \\
\hline 知覚差異 & 0.456 & 2.365 & 0.124 & 1.578 & 0.882 & 2.823 \\
\hline 馴染み & -0.154 & 0.252 & 0.615 & 0.857 & 0.470 & 1.563 \\
\hline 属性重要度 & -0.366 & 1.188 & 0.276 & 0.694 & 0.360 & 1.339 \\
\hline 定数 & -3.625 & 3.602 & 0.058 & $0.027^{\star}$ & & \\
\hline
\end{tabular}

$\chi^{2}(8)=4.153 p=0.843 \quad$ 予測值の正分類: $96.0 \%$

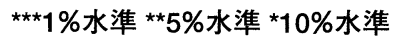

3. 評価一致型推論

\begin{tabular}{|c|c|c|c|c|c|c|}
\hline & \multirow{2}{*}{ B } & \multirow{2}{*}{ Wald } & \multirow{2}{*}{ 有意確率 } & \multirow{2}{*}{$\begin{array}{l}\text { オッズ比 } \\
(\operatorname{Exp}(B))\end{array}$} & \multicolumn{2}{|c|}{ Exp (B) の95.0\%信頼区間 } \\
\hline & & & & & 下限 & 上限 \\
\hline 相関関係 & -0.292 & 11.054 & 0.001 & $0.747^{\star \star \star}$ & 0.629 & 0.887 \\
\hline 効率性 & -0.114 & 1.377 & 0.241 & 0.892 & 0.737 & 1.080 \\
\hline 知覚差異 & 0.158 & 2.615 & 0.106 & 1.172 & 0.967 & $1.41 \mathrm{c}$ \\
\hline 馴染み & -0.265 & 5.969 & 0.015 & $0.767^{\star \star}$ & 0.620 & 0.949 \\
\hline 属性重要度 & 0.184 & 2.741 & 0.098 & $1.202^{\star}$ & 0.967 & 1.495 \\
\hline 定数 & 0.629 & 0.939 & 0.332 & 1.876 & & \\
\hline
\end{tabular}

$\chi^{2}(8)=11.365 \mathrm{p}=0.182 \quad$ 予測值の正分類: $59.8 \% \quad{ }^{* * *} 1 \%$ 水準 ${ }^{* *} 5 \%$ 水準 ${ }^{*} 10 \%$ 水準

4. 他ブランド平均型推論

\begin{tabular}{|c|c|c|c|c|c|c|}
\hline & \multirow{2}{*}{ B } & \multirow{2}{*}{ Wald } & \multirow{2}{*}{ 有意確率 } & \multirow{2}{*}{$\begin{array}{l}\text { オッズ比 } \\
(\operatorname{Exp}(\mathrm{B}))\end{array}$} & \multicolumn{2}{|c|}{ Exp (B) の95.0\%信頼区間 } \\
\hline & & & & & 下限 & 上限 \\
\hline 相関関係 & -0.701 & 12.863 & 0.000 & $0.496^{\star \star \star}$ & 0.338 & 0.728 \\
\hline 効率性 & 0.300 & 2.830 & 0.092 & $1.349^{\star}$ & 0.952 & 1.913 \\
\hline 知覚差異 & -0.338 & 4.214 & 0.040 & $0.714^{\star \star}$ & 0.517 & 0.985 \\
\hline 馴染み & 0.324 & 2.351 & 0.125 & 1.383 & 0.914 & 2.092 \\
\hline 定数 & -1.002 & 1.014 & 0.314 & 0.367 & & \\
\hline
\end{tabular}


くなっている $(\operatorname{Exp}(\mathrm{B})=0.547 、 \mathrm{p}<0.05)$ 。これ は、属性間の相関関係が 1 単位増加すると、代 償型推論遂行のオッズが低下する (45.3\%減に なる）ことを表している。すなわち、属性間 の相関関係が強くなると代償型推論は遂行さ れにくくなるので、H1bは支持された。また、 市場の効率性におけるオッズ比は 1 よりも大 きくなっているので $(\operatorname{Exp}(\mathrm{B})=1.651 、 \mathrm{p}<0.05)$ 、 市場の効率性が高くなると代償型推論が遂行 されやすくなることがわかる。よって H2a は 支持された。

内的要因では、製品カテゴリーへの馴染み が深まると代償型推論の遂行割合が大きくな ると予想したが、パラメータ推定值は有意に ならず、オッズ比の值だけをみても 1 より小 さかった $(\operatorname{Exp}(\mathrm{B})=0.857 、 \mathrm{p}>0.10)$ 。よって、 $\mathrm{H} 4 \mathrm{~b}$ は支持されなかった。

\section{・評価一致型推論}

表 5-3には、評価一致型推論の遂行／非遂 行を目的変数とするロジスティック回帰分析 の結果が示されている。評価一致型推論では、 属性間の相関関係におけるオッズ比が 1 より も小さくなっているので $(\operatorname{Exp}(\mathrm{B})=0.747$ 、 $\mathrm{p}<0.01)$ 、属性間の相関関係が強くなると評価 一致型推論は遂行されにくくなるといえる。 よって、H1cは支持された。一方、市場の効率 性とブランド間知覚差異におけるオッズ比の 值を見ると、市場の効率性は 1 より小さく、ブ ランド間知覚差異は 1 より大きなっている

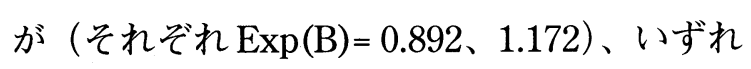
も統計的に有意ではなかった。よって市場の 効率性が高いほど評価一致型推論の割合が小 さくなるという H $2 b$ 、およびブランド間知覚 差異が大きいほど当該推論の割合が大きくな るという H3aは部分的には支持されるものの、 完全に支持できる結果とはならなかった。

また、評価一致型推論では、仮説として提
示しなかった製品カテゴリーへの馴染みと属 性重要度に関しても有意な結果が得られ、 オッズ比の值から、これら2つの内的要因が 当該推論の遂行に負の影響を及ぼすことが明 らかになった（それぞれ $\operatorname{Exp}(\mathrm{B})=0.767$ 、 $\mathrm{p}<0.05 、 \operatorname{Exp}(\mathrm{B})=1.202 、 \mathrm{p}<0.10)$ 。

\section{・他ブランド平均型推論}

表 5-4には、他ブランド平均型推論の遂行 /非遂行を目的変数とするロジスティック回 帰分析の結果が示されている。他ブランド平 均型推論では、属性間の相関関係とブランド 間知覚差異においてオッズ比が 1 より小さく なっている（それぞれ $\operatorname{Exp}(\mathrm{B})=0.496 、 \mathrm{p}<0.01$ 、 $\operatorname{Exp}(\mathrm{B})=0.714 、 \mathrm{p}<0.05)$ 。したがって、属性間 の相関関係およびブランド間知覚差異が増す と他ブランド平均型推論が遂行されにくくな るといえるので、H1d およびH3b は支持され た。しかし、市場の効率性におけるオッズ比 は1より大きくなっており $(\operatorname{Exp}(\mathrm{B})=1.349$ 、 $\mathrm{p}<0.10)$ 、市場の効率性が高くなると他ブラン ド平均型推論は遂行されやすくなるという結 果が得られた。よって、H2cは支持されなかっ た。

なお、他ブランド平均型推論のロジス ティック回帰モデル（表5-4）には属性重要度 が含まれていないが、これは確率型推論にお ける市場の効率性と同様に、当該説明変数の パラメータ推定值が有意にならず、なおかつ これを含めた場合にモデルの適合度が低かっ たことによるものである。

\section{6. 考察}

分析の結果、次のような知見が得られた。 第一に、確率型推論には属性間の相関関係、 製品カテゴリーへの馴染み、推論対象属性の 重要度が正の影響を及ぼす。つまり、推論対 象属性と強い相関関係にあると知覚される属 
性が存在し、その属性に関する情報が利用可 能であるならば、他の外的要因に影響される ことなく確率型推論が遂行されやすくなる。 しかし、属性間の相関関係に関する知識は、 カテゴリーへの馴染みが深まるにつれてより 明確に形成されていくので、製品カテゴリー への馴染みが深いほど確率型推論が遂行され やすくなると考えられる。また、確率型推論 は推論対象属性の水準をより直接的な方法で 予測するタイプの推論であるため、推論対象 の属性が重要であるほど遂行されやすくなる といえよう。

第二に、代償型推論には属性間の相関関係 が負の影響を及ぼし、市場の効率性が正の影 響を及ぼす。したがって、推論対象属性と強 い相関関係にあるような属性が存在せず、当 該製品市場の効率性が高い場合には代償型推 論が遂行されやすくなると考えられる。一方、 仮説段階では代償型推論に正の影響を及ぼす と考えられた製品カテゴリーへの馴染みが、 有意ではないものの負の影響を及ぼすことが 明らかになった。池尾（1999）は消費者の購 買決定全体において価格が果たす役割を論じ た際、製品判断力の低い消費者ほど、品質一 価格関係（価格が製品内容の判断基準となる 関係）を重視するようになると述べている。 代償型推論は（総合的な意味での）品質一価 格関係に基づく推論であり、製品判断力の高 さは製品カテゴリーへの馴染みを反映すると 考えれば、製品カテゴリーへの馴染みは（弱 いながらも）負の影響をもたらすと考えるべ きかもしれない。

第三に、評価一致型推論には属性間の相関 関係、製品カテゴリーへの馴染み、属性の重 要度が負の影響を及ぼす。つまり、推論対象 属性と強い相関関係にあるような属性が存在 しない、製品カテゴリーへの馴染みが薄い、 あるいは推論対象の属性がそれほど重要でな
い場合、評価一致型推論が遂行されやすくな る。評価一致型推論には市場の効率性とブラ ンド間知覚差異がそれぞれ負と正の影響を及 ぼすと予想したが、有意な結果は得られな かった。しかし、数值はこれと同様の方向を 示していたので、そのような影響が考えられ るものの、当該推論タイプの遂行割合を左右 するほどのインパクトはないと考えるのが妥 当であろう。

最後に、他ブランド平均型推論には属性間 の相関関係とブランド間知覚差異がともに負 の影響を及ぼし、市場の効率性は正の影響を 及ぼす。市場の効率性については、仮説（当 該推論の遂行割合に負の影響を及ぼす）と全 く逆の結果であった。これは、「価格は同一」 という条件を目にした回答者が、他の属性水 準を考慮することなく「効率性が高い市場の 製品で価格が同一ならば、どれも同じ」と短 絡的に考えたとも解釈できる。こうした現象 は消費者による情報処理の量やモチベーショ ンとも関連しており、今後検討する必要があ るだろう。

\section{7. おわりに}

\section{1 インプリケーション}

本研究の結果から、次のようなインプリ ケーションを得ることができる。第一に、 マーケターは主にコミュニケーションの領域 において、自らが提供する情報の効果だけで なく、提供されない情報の影響にも注意すべ きである。本研究が示すように、消費者は与 えられた情報から未知の情報について推論す る。しかもその方法は一通りではなく、さま ざまな要因の影響を受けて異なるタイプの推 論が遂行される。これは、同じ属性について 推論する場合であっても、状況によって結論 が異なることを意味する。例えば、代償型推 論をするのと評価一致型推論をするのでは、 
未知の属性に対する信念が全く変わってしま う。

したがってマーケターは、訴求しようとし ている属性と他の属性の関係、自社が対象と している市場の効率性、あるいはブランド間 知覚差異について理解しておかなければなら ない。そして、コミュニケーション上訴求さ れない属性に対しても、消費者がどのような 信念を形成する可能性があるか考慮する必要 がある。例えば、代償型推論が行われやすい 高効率性市場で競争するマーケターの場合、 単に自社製品の優位性を訴求するだけでは十 分でない。代償型推論によって本来の訴求点 が打ち消されることのないよう、リーダー企 業であれば当該市場の効率性が低いことを示 して評価一致型推論を誘発したり、二番手以 降の企業であれば重要度の低い属性で自社製 品の劣位性を示したりするといった対策が求 められる。

本稿では、これまで単なる記述レベルにと どまっていた消費者推論と内的要因の関係も モデルに含めて検証し、内的要因が各推論タ イプの遂行に及ぼす影響を明確に示した ${ }^{11 。}$ 例えば、評価一致型推論は馴染みの薄い製品 カテゴリーや重要度の低い属性に対して行わ れやすいことが明らかになったが、こうした 知見は消費者推論についての理解を深めると ともに、ブランド論やハロー効果といった テーマとも関連づけることができよう。

\section{2 本研究の限界}

本研究は多くの限界も有している。まず、 調査の妥当性について触れておかなければな らない。1つ目は測定の妥当性、とりわけ基準 妥当性に関する問題である。今回、「価格が同 一であれば、どのメーカーやブランドの製品 を購入しても、総合的な品質はほとんど同じ だと思うか」という質問で市場の効率性を測
定した。その結果、市場の効率性が高い製品 カテゴリーとしてミネラルウォーターが採用 された。しかし、現在、ミネラルウォーター はその効能が広く謳われており、単なる飲料 水という枠を越え様々な目的で使用されるよ うになっているものの、その効果を確認する ことは非常に困難な製品である。したがって、 この測定結果は高効率性市場の特徴（低い情 報探索コスト、明瞭なべネフィット、容易な ベネフィット評価）と適合しているとは言い 難く、質問内容について今一度吟味する必要 がある。

$2 つ$ 目は、外部妥当性に関する問題である。 今回の調査は学生という偏った層を対象に実 施されたものであり、ここでの結果をもって 消費者行動一般について論じられないことは 明らかである。また、各ブランドの属性水準 についても一律 5 点満点で点数化して示した が、通常、異なる属性の水準は尺度 (単位) が 異なっているため容易に比較できない。こう した問題点に加え、今回の知見はミネラル ウォーターとワインという製品を対象とした 場合の調查結果から得られたものであり、他 の製品カテゴリーへ一般化するには、さらな る経験的テストの蓄積が必要であることは言 うまでもない。また、今回の調査は、客観的 特性と主観的属性を明確に区別することなく デザインされていたが、客観的属性と主観的 属性には判断の容易性や消費者の確信度など 異なる点も多い。今後はその相違を明確にし た上で実験を行う必要もあるだろう。

最後に、今回はサンプル数などの制約から 取り上げることができなかったが、本稿で取 り上げた要因以外にも、推論タイプに影響を 及ぼすと思われる要因があることを指摘して おく。それは「課題の複雑性」であり、選択 肢数、属性数、あるいは時間的制約によって 採用される推論タイプに違いが生じるといわ 
れている（Chernev and Carpenter 2001）。こ れは、前節で述べた情報処理の量やモチべー ションとも関わりのある要因だろう。

このように、本研究には限界も多く、今後 の課題も残されている。しかし、本研究はこ れまで断片的に示されていた推論のタイプと 影響要因について整理し、限定された状況の 下ではあるが、両者の関係を明確に示すこと ができた。今後、更なる研究を進め、消費者 推論の適用範囲を広めるとともに、推論に よって形成された属性信念が意思決定全体に 及ぼす影響などについても明らかにすること ができれば、推論研究の価值は一層高まるだ ろう。

\section{〈謝辞〉}

本稿の作成にあたっては、本誌のエディ ターおよびレビューアーの先生方に貴重なア ドバイスを頂いた。ここに記して深く感謝申 し上げたい。

\section{〈注〉}

1. これは極めて限定された状況であり、推論の一 面しか捉えていないという欠点もあるが、議論 の焦点を明確にするという目的から採用した。

2. 新倉（1999）にも同様の主張が確認できる。

3. 平均值の差は、7つの製品カテゴリー全てを対 象に多重比較 (TukeyのHSD検定)を行って検 定した。

4. 提示した属性はミネラル含有量、ダイエット効 果、健康効果、飲みやすさ、原産地の自然環境、 安全性（以上ミネラルウォーター）、生産地の 気候条件、生産地の土堙条件、ポリフェノール 含有量、健康効果、味の深み、生産者のレベル (以上ワイン) である。

5. Dunnettの検定とは対照として 1 つのグループ を設定し、それと他の全てのグループを比較す る方法である。
6. これら一連の処理が妥当であるか確認するた め、推論課題の後に「なぜそう思うのか」とい う質問を設けた (自由回答形式)。その結果、大 部分の回答者は筆者が想定した通りの理由を記 述したが、全く異なる選択理由を述べた回答者 が5名（男性1名、女性4名）存在したため、そ れらは分析の対象から除外した。したがって、 最終的な有効サンプル数は301名（男性 197名、 女性 104 名）である。

7. 属性間の相関関係については、属性 $\mathrm{A}$ と推論対 象属性についてのみ測定した。

8. 加えて、今回の調査から得られたクロス表 (表4) のように、期待值が 5 未満となるセルが存在す る場合、 $\chi^{2}$ 統計量は理論的な $\chi^{2}$ 分布へ近似し にくくなることが知られている。

9. 本来ならば、序数尺度はダミ一変数化して扱う べきだが、ここでの関心は重要度の変化が及ぼ す影響にあり個々の順位が及ぼす影響ではない ため、あえて量的に扱った。

10. 今回の調査データでは 5 つの説明変数が全て量 的であるため、プロファイル（説明変数群の值 の組み合わせ)の数が大きくなり、1つひとつの プロファイルに含まれる実測データ数が少なく なる。このような場合、デビアンス（尤度比検 定統計量) およびPearson $\chi^{2}$ 統計量は理論的な 攵分布へ近似しないことが知られている。そこ で、この問題を解消できる Hosmer-Lemeshow 検定（データを適宜分割して $\chi^{2}$ 検定する方法 であり、ここでは 10 分割とした。自由度は分割 数マイナス 2)によって適合度を確認した。

11. Alba and Hutchinson（1987）では、消費者の熟 達度や情報処理能力といった視点から、消費者 推論に関する詳細なレビューが行われている。

\section{〈参考文献〉}

Alba, Joseph W. and J. Wesley Hutchinson (1987), "Dimensions of Consumer Expertise," Journal of Consumer Research, 13(March), pp.411-454. 
Bettman, James R., Deborah Roedder John, and Carol A. Scott (1986), "Covariation Assessment by Consumers," Journal of Consumer Research, 13 (December), pp.316-326.

Broniarczyk, Susan M. and Joseph W. Alba (1994), "The Role of Consumers' Intuitions in Inference Making," Journal of Consumer Research, 21 (December), pp.393-407.

Chernev, Alexander and Gregory S. Carpenter (2001), "The Role of Market Efficiency Intuitions in Consumer Choice: A Case of Compensatory Inferences," Journal of Marketing Research, 38 (August), pp.349-361.

Dick, Alan, Dipankar Chakravarti, and Gabriel Biehal(1990), "Memory-Based Inference During Consumer Choice," Journal of Consumer Research, 17(June), pp.82-93.

Ford, Gary T. and Ruth Ann Smith (1987), "Inferential Beliefs in Consumer Evaluations: An Assessment of Alternative Processing Strategies," Journal of Consumer Research, 14 (December), pp.363-371.

Huber, Joel and John McCann (1982), "The Impact of Inferential Beliefs on Product Evaluations," Journal of Marketing Research, 19 (August), pp.324-333.

池尾恭一（1999）『日本型マーケティングの革新』 有斐閣。

Lee, Dong Hwan and Richard W. Olshavsky (1997), "Consumers' Use of Alternative Information Sources in Inference Generation: A Replication Study," Journal of Business Research, 39 (July), pp.257-269.

Lichtenstein, Donald R. and Scot Burton (1989), "The Relationship between Perceived and Objective Price-Quality," Journal of Marketing Research, 26(November), pp.429-443.

Lim, Jeen-Su and John Kim (1992), "Impact of Con- sumers' Confidence in Judgements about Missing Information on Product Evaluations," Journal of Business Research, 25 (November), pp.215229.

Meyer, Robert J. (1981), "A Model of Multiattribute Judgements under Attribute Uncertainty and Informational Constraint," Journal of Marketing Research, 18 (November), pp.428-441.

Moon, Junyean and Surinder Tikoo (1997), "Consumer Use of Available Information for Making Inferences about Missing Information," Journal of Business Research, 39 (June), pp.135-146.

中西正雄（1984）「消費者行動の多属性分析」中西 正雄編『消費者行動分析のニュー・フロンティ アー多属性分析を中心に一』誠文堂新光社 2-26 頁。

新倉貴士 (1996)「共変信念と理論駆動型処理：カ テゴリー・ベース処理の解明に向けて」『商学論 究』第 43 巻第 $2 \cdot 3 \cdot 4$ 合併号 161-177頁。

新倉貴士 (1997)「カテゴリー・ベース処理と共変 信念一市場の境界線を求めて一」『マーケティン グ・サイエンス』第 5 巻第 1・2 号 39-55 頁。

新倉貴士 (1999)「知覚符号化の二つの側面 一属 性水準と知覚符号化一」『商学論究』第 46 巻 第 5 号 73-87 頁。

Pechmann, Cornelia and S. Ratneshwar (1992), "Consumer Covariation Judgments: Theory or Data Driven?" Journal of Consumer Research, 19 (December), pp.373-386.

Rao, Akshay R. and Kent B. Monroe (1988), "The Moderating Effect of Prior Knowledge on Cue Utilization in Product Evaluations," Journal of Consumer Research, 15 (September), pp.253264.

Rosen, Sherwin (1974), "Hedonic Prices and Implicit Markets: Product Differentiation in Pure Competition," Journal of Political Economy, 82(January/February), pp.34-55. 
Ross, William T., Jr., and Elizabeth H. Creyer (1992),

"Making Inferences about Missing Information: The Effects of Existing Information," Journal of Consumer Research, 19 (June), pp.14-25.

Simmons, Carolyn J. and John G. Lynch, Jr. (1991), "Inference Effects without Inference Making? Effects of Missing Information on Discounting and Use of Presented Information," Journal of Consumer Research, 17 (March), pp.477-491.

Simmons, Carolyn J. and Nancy H. Leonard (1990), "Inferences about Missing Attributes: Contingencies Affecting the Use of Alternative Information Sources," Advances in Consumer Research, 17, pp.266-274.

\section{〈Appendix〉}

例として、強相関／高効率性／大知覚差異 群の質問項目を以下に示しておく。

\section{推論課題}

スーパーマーケットの店内に 3 つのミラル ウォーター（ブランド A、ブランド B、ブラン ドC）が展示されています。3つのミネラル ウォーターの価格は同一ですが、それぞれの 製品に対し、「原産地の自然環境」「ダイエッ 卜効果」「製品（ミネラルウォーター自体）の 安全性」という点について専門家（店舗や メーカーとは無関係の人物）が 5 点満点で評 価しています。

\begin{tabular}{lccc}
\hline & $\begin{array}{c}\text { 原産地の } \\
\text { 自然環境 }\end{array}$ & $\begin{array}{c}\text { ダイエット } \\
\text { 効果 }\end{array}$ & $\begin{array}{c}\text { 製品の } \\
\text { 安全性 }\end{array}$ \\
\hline ブランドA & 5 & 3 & 2 \\
\hline ブランドB & 2 & 2 & 3 \\
\hline ブランドC & 3 & 5 & 5 \\
\hline
\end{tabular}

Q. 3 ブランドの評価が表のように下されて いる場合、3つのブランドのうち、ミネラル (ナトリウムやカルシウムなど) が最も多く含 まれていると思うミネラルウォーターはどれ ですか。
1. ブランド A
2. ブランド B
3. ブランド C
4. どれも同じ

影響要因に関する質問

Q．優れた自然環境にある場所で採取された ミネラルウォーターほど、ミネラル（ナトリ ウムやカルシウムなど）が多く含まれている と思いますか。(属性間の相関関係)

Q．価格が同一であれば、どのメーカーやブ ランドのミネラルウォーターを購入しても、 総合的な品質はほとんど同じだと思いますか。 (市場の効率性)

Q．ミネラルウォーターに含まれているミネ ラルの量は、価格が同一であってもメーカー やブランドによって差があると思いますか。 (ブランド間知覚差異)

以上 3 項目は「1. そう思わない〜 5. そう思う」 （間隔尺度）によって測定

Q．あなたは、平均的な消費者（ここでは、 一ヶ月に一度の割合で購入している消費者と します）と比較して、どの程度ミネラル ウォーターを購入していますか。(製品カテゴ リーへの馴染み：購入頻度）

Q．あなたは、平均的な消費者（同上）と比 較して、どの程度ミネラルウォーターを飲み ますか。(製品カテゴリーへの馴染み:使用頻 度)

以上 2 項目は「1. 非常に少ない 2. やや少な い 3. 同じ 4. やや多い 5. 多い」によって 測定 
Q．あなたは、ミネラルウォーターについて

詳しいと思いますか。(製品カテゴリーへの馴

染み：知識）

「1. そう思わない〜 5. そう思う」（間隔尺度）

によって測定

Q。下に挙げる項目について、ミネラル ウォーターを購入する際に重要だと思う順に （）の中へ番号を付けてください。（属性 重要度)

原産地の自然環境（）

ダイエット効果（）

製品 (ミネラルウォーター自体) の安全性（）

ミネラルの含有量 $(\quad)$ 